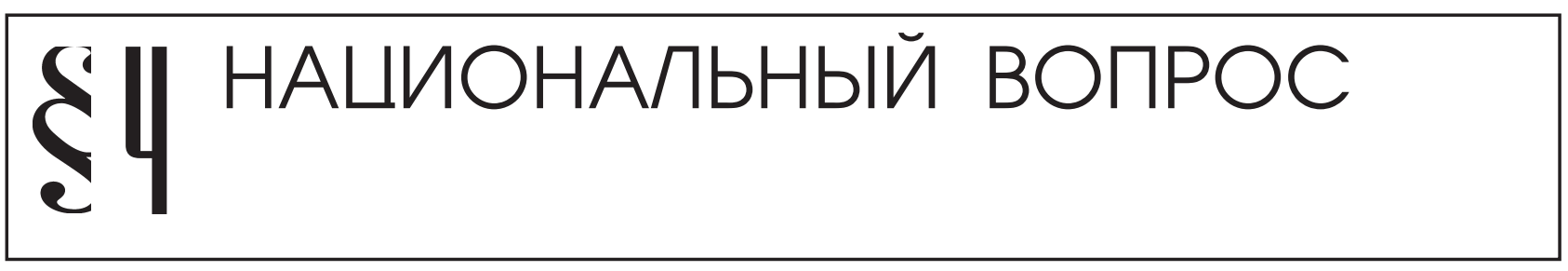

А.С. Разин

\title{
СТАНОВЛЕНИЕ ЭТНОКОНФЕССИОНАЛЬНЫХ ОТНОШЕНИЙ В РОССИЙСКОМ СОЦИУМЕ: ПОЛИТИКО-ФИЛОСОФСКИЙ АНАЛИЗ
}

Аннотация: Взаимоотношения национального и религиозного вызывают массу споров и дискуссий в современной сочиальной философии и общественно-гуманитарных науках. Данная проблема актуальна не только в свете геополитических изменений, но и благодаря так называемому «идентификационному буму», который характеризует состояние общественного сознания, «жизненный мир» социальных групп и индивидов на постсоветском пространстве.

Ключевые слова: Философия, этноконфессиональные отношения, самоидентификачия, национальность, этнос, религия, конфессия, религиозный фактор, исламский фактор, этноконфессиональный фактор

B современной социальной философии и этнической социологии доминирующей стала иная тенденция, согласно которой национальность является продуктом самоидентификации личности ${ }^{1}$, то есть субъективного самоопределения человека. При таком подходе критерием национальности, как мы видим, становится не традиционный кровнородственный фактор, а один из элементов самосознания человека.

Сегодня более востребованной является синтетическая концепция национальности. Это означает, что термин «национальность» должен, с одной стороны, подразумевать принадлежность к определенной социально-этнической общности - нации, народности, этнической группе - a, с другой, являться результатом субъективного осознания, самоидентификации личности с этой группой.

Социально-этническая общность, включающая племя, народность, нацию, существует объективно и имеет такие существенные признаки как экономика, территория, уклад жизни, особенности жизнедеятельности, обладает специфическими трансцендентальными характеристиками (отношение к миру, ментальность, этноним (самоназвание) и др.).

${ }^{1}$ Marody M. On functions of religion in molding the national identity of poles // Intern. J. of sociology. - Annonk, 2005-2006. - N 4. - P. 49-68.
Наличие в государстве, различных социально-этнических общностей, обусловливает наличие национальных отношений, существующих в трех формах:

- внутринациональные связи;

- взаимоотношения социально-этнических общностей;

- межличностные отношения представителей различных национальностей.

Понятие «религиозное» относится к индивидам и общностям, в том числе и этническим, характеризующимся наличием религиозного сознания. Именно этносы выступают субъектами религиозной деятельности и религиозных отношений. При этом следует иметь в виду, что современная наука различает понятия «религиозная и нерелигиозная деятельность» и «религиозные и нерелигиозные отношения» применительно к религиозным субъектам². Религиозная деятельность - внекультовая и культовая - это деятельность религиозных индивидов, групп, институтов и организаций, которая выражается в разработке вероучения и в его пропаганде, в подготовке кадров духовенства, в различных формах культовых актов.

Как правило, подобного рода деятельность не выступает компонентом внешних религиозных (т.е. межрелигиозных) отношений. Обычно в качестве такового

${ }^{2}$ Разин А.С. Этноконфессиональные факторы хозяйствования в постиндустриальном обществе // Философия и культуpa -2012 , - №3, - С. 55. 


\section{Политика и общество 2 (98) • 2013}

выступает преимущественно нерелигиозная деятельность религиозных субъектов - политическая, экономическая. Нерелигиозная деятельность зачастую приобретает религиозную окраску («религиозная политика», «исламский банкинг» и т.п.) или интерпретацию, но, по своему объективному содержанию, она - собственно внерелигиозная деятельность. Аналогичным образом обстоит дело и с религиозными отношениями.

Религия и этнос являются важнейшими компонентами современной социальной системы. Поэтому значительный научный интерес представляет исследование этнических и религиозных отношений как сложных многофункциональных общественных образований, а также изучение их роли в динамике общества, специфика взаимопроникновения и взаимодействия. Анализ связи религии и этноса требует особого внимания к существующему категориальному аппарату. Прежде всего, это касаются таких понятий, как «конфессия», «конфессиональная специфика», «этническая специфика».

Как известно, конфессия (от лат. confessio), - признание, исповедание. По мнению родоначальника этноконфессиональной проблематики в отечественной науке А.Н. Ипатова, конфессией можно считать вероисповедное направление, возникшее в той или иной религиозной системе в ходе социально-исторического развития общества, специфически сочетающее в себе вероучительные, культовые и организационно-структурные особенности этой системы ${ }^{3}$. Таким является христианство, которое отличается чрезвычайной многоконфессиональностью. Оно включает католицизм, православие, лютеранство, англиканство, кальвинизм, меннонитство, баптизм. Сегодня многие из этих церквей носят этнически выраженный характер, приобретенный ими в результате длительного этноконфессионального взаимодействия ${ }^{4}$.

Как известно, именно на такой основе происходит в сознании людей отождествление конфессиональной и национальной принадлежности, которое находит выражение в виде дихотомной схемы «поляк-католик», «русский-православный». Для «конфессии» характерны достаточно высокий уровень самосознания, организации и институализации, со своим центром догматики.

\footnotetext{
${ }^{3}$ Ипатов А.Н. Православие и русская культура. - М.: 1985. C.22.

${ }^{4}$ См. об этом: Достоян И.С. Карасев А.В. Православная церковь и складывание сербской нации. - М., 1999. - С. 138.
}

В данном направлении интересны исследования современного канадского ученого М. Бушара 5 . Анализируя письменные памятники средневековой Руси, в частности: Псалтирь, «Повесть временных лет», «Слово о законе и благодати» митрополита Иллариона, М. Бушар приходит к следующим выводам:

- русская нация обязана своим образованием не столько государству, как полагает большинство исследователей, сколько православию;

- древнейшие письменные религиозные памятники, особенно Псалтырь, ясно показывают, что истоки русской нации лежат в православной вере.

Православие явилось одним из объединительных и созидательных факторов, послуживших «превращению» населения Киевской Руси в единый русский народ. На ранних стадиях развития русской нации именно единая православная вера стала той парадигмой, что лежала в основе национального самосознания русского народа. Крещение Руси следует рассматривать как отправную точку формального отсчета становления России. Наверное, здесь и следует искать истоки русского этноса и его национального самосознания.

Не секрет, что этнические и конфессиональные общности имеют значительную культурную специфику. При этом они не равнозначны ни содержательно, ни хронологически. Этнические различия, как и традиционные различия в религиях, по мысли американского антрополога Роджера Брубакера, универсальны для человечества в каждый исторический период его существования ${ }^{6}$.

Изучение религий Древнего Востока и Античности, таких, как египетская, вавилонская, сирийская, греческая, обнаруживает у них тесную связь между конфессиональной и этнической спецификой. Похожими были не только этнические признаки, но и жертвоприношения и процессии, соблюдение предписаний относительно приема пищи и омовений. Только так можно было доказать свою принадлежность к определенной религии ${ }^{7}$.

Взаимосвязь этнической специфики с конфессиональной проявлялась и в том, что принадлежность ин-

\footnotetext{
5 Бушар Мишель Православие как идеологическая основа становления русской нации // Этнографическое обозрение. 2002. №4 c.139-149.

${ }^{6}$ Brubaker $R$. Ethnicity as cognition // Theory a. society. - Dordrecht, 2004. - N 33. - P.31-64.

${ }^{7}$ Firth R. Religion in social reality // Elements of social organization. - L.: Watts \& Co., 1951. - P.215-250.
} 
Национальный вопрос

дивида к определенной религии выступала в качестве его этнической принадлежности. Результаты взаимодействия религии и специфики того или иного этноса были по существу этноконфессиональными. Социальная зрелость этноса (завершение формирования некоторой общности или группы как этнической) характеризуется созданием собственной религиозноценностной системы.

Рассматривая связи религии с этносом, с происходящими в нем процессами, лежащими в основе его формирования и изменения, необходимо отметить, что религия, будучи сопряженной с этими процессами, играет в одно и тоже время двойственную, как этноразделительную, так и этноинтегрирующую роль. Она всегда выступала в двух ипостасях. Однако во многих ситуациях религия, благодаря тесной связи с динамичными и подвижными элементами психологии масс, укрепляла сцепляющие связи внутри этноса и тем самым противодействовала ассимиляции его завоевателями. Самым ярким примером может служить история еврейского народа, который находясь в диаспоре около двух тысячелетий, благодаря иудаизму, сохранил свой язык, традиции, самосознание, культ ${ }^{8}$.

Таким образом, основные тенденции формирования социальных связей между религией и этносом проявляются в сфере взаимодействия конфессиональной и этнической специфики.

Первая тенденция - это «конфессионализация» этнических явлений и свойств, при которой ряд особенностей культуры и быта в течении длительного взаимодействия впитываются культом, становятся его составными элементами. Исключительное значение религии в создании и укреплении этнической общности подчеркивал еще в начале XX в. французский философ и социолог Эмиль Дюркгейм. Он отмечал, что религия освящает фундаментальные социальные связи общества, что придает социальным группам целостность. То, что священно, живет не столько в официальных законах, сколько в душе и совести живого человека 9 .

Анализируя идеи Дюркгейма, российский ученый Д.В. Пивоваров отмечает, что религия компенсирует недостатки рациональной науки, дает свое понимание смысла и назначения жизни, общества, нации, класса, человека. «Религия, - продолжает Пивоваров, есть

\footnotetext{
${ }^{8}$ См., например: Роль религии в формировании южнославянских наций. - М.: 1999. - 264 с.

9 Дюркгейм Э. Социология религии и теория познания // Религия и общество. - М.-1996. С 113.
}

особая духовно-практическая связь между людьми, основанная на священном отношении к таким ценностям (идеям, процессам, действиям, людям, вещам, миру в целом), которые признаются верующими наиболее важными для укрепления единства их сообщества» ${ }^{10}$.

По мнению другого ученого, В.И. Корнева: «Религия не только придает специфику социокультурному пространству, но и формирует психологию сообщества данного пространства, иначе говоря, именно религия создает психосоциокультурное пространство-время, которое способно вместить многие народы и этносы» ${ }^{11}$.

Вторая тенденция - это «этнизация» конфессиональных явлений и отдельных компонентов культового комплекса, (особенно его ритуалов, религиозных обычаев и традиций), через проникновение его в национальные формы общественной жизни посредством слияния с народными верованиями, которые этногенетичны. Конфессиональные явления приобретают характер этнических явлений, этнически окрашиваются. Следует заметить, что конфессия «этнизируется» лишь тогда, когда ее представители проживают компактно. Именно в этом случае религиозные отличия проникают глубоко в быт, а вероучение, если оно было воспринято («прозелетично»), наследуется уже, как минимум, в нескольких поколениях ${ }^{12}$.

Таковы две основные тенденции образования взаимосвязей между религией и этносом. В результате их действия складывающиеся связи между конфессией и рядом признаков этнической общности (традиционные формы хозяйства и образа жизни, культурно-бытовая специфика, язык, этническое самосознание и др.) оказывают влияние на срастание религии с социальным опытом людей, на формирование в будущем народностей и наций. Укажем, что все мировые религии космополитичны, не признают существование наций, основанных на этническом принципе. Например, ислам признает только «умму» т.е. сообщество правоверных то, для христианства «нет ни эллина, ни иудея» ${ }^{13}$.)

\footnotetext{
${ }^{10}$ Пивоваров Д.В. Религия: взаимосвязь натуроцентрической и социоцентрической форм // Религия, общество и государство в ХХ в. М., 1991. С.102.

${ }^{11}$ Корнев В.И. Феномен религии // Азия и Африка сегодня. - 1994.-№1. c. 33

${ }^{12}$ Schnee $W$. Nationalism: A review of the literature // J. of polit. a. milit. sociology. - New Brunswick, 2001. - N 1. - P. 1-18.

${ }^{13}$ См. об этом: Мирский Г. Этнос, религия, национализм// Азия и Африка сегодня. 1994. №2. С.4.
} 


\section{Политика и общество 2 (98) • 2013}

Согласно мнению Л.Н. Митрохина, в конкретной национальной культуре религия не просто оболочка, или «внешний идеологический пласт», а «особая наука жизни», которая глубоко укоренена в хозяйственной деятельности людей, пронизывая их мироощущение ${ }^{14}$. Религиозные представления и процессы в национальном самосознании характеризуются во многом сходными чувствами, переживаниями, настроениями, эмоциональным состоянием людей. Они имеют возможность накладываться друг на друга, образуя общую, усиливающуюся при этом направляющую практического выражения данного чувственно-психологического состояния.

Таким образом, этноконфессиональные отношения представляют собой, с одной стороны, форму отношений верующих к гипостазированным существам, свойствам, связям (прежде всего к Богу), с другой - форму отношений верующих друг с другом, как в рамках своей общины и конфессии, так и вне их. В рамках последнего вида отношений представители разных религий все чаще входят в сферу внерелигиозных отношений, они активно обсуждают вопросы войны и мира, экономики, социальную проблематику. Вовлеченность религиозных субъектов в область данных отношений объективно не может быть отнесена к сфере религиозных отношений, хотя субъективно в эти отношения может вкладываться и вкладывается определенный религиозный смысл.

Резюмируя, может сказать, что этноконфессиональные отношения это сложное взаимодействие между этническими общностями, и их институтами с одной стороны, и последователями разных религий и существующих в их рамках конфессий, а также субъектами этих религий и конфессий (религиозными группами, органами управления религиозных объединений, служителями церкви), с другой.

В нашей науке существует несколько различных определений, касающейся «этноконфессиональной общности». Например, В.Н. Рагузин придает ей более глубокий смысл, когда пишет, что «... это особый тип социальной общности людей, с религиозно оформленным жизненным укладом, этническим самосознанием. Она выступает как религиозная общность, но в конкретных социально-исторических условиях играет функции этнического определителя» ${ }^{15}$.

\footnotetext{
${ }^{14}$ Митрохин Л.Н. Философия религии: новые перспективы // Вопр. философии. - 2003. - №8. С.23.

15 Рагузин В.Н. На острие российской геополитики. - М.: 1999. c.74.
}

Следует подчеркнуть, что совпадение этнической и религиозной принадлежности не означает их тождества или нераздельности. Эти понятия фактически неотождествимы, так как большинство важнейших признаков и характерных черт этноса не могут прилагаться к общности религиозной. Как отмечают С.И. Брук, Н.Н. Чебоксаров, Я.В. Чеснов, этноконфессиональные общности «не могут считаться народами или этносами в прямом смысле этого слова. Для того, чтобы сложилась собственно этническая общность любого порядка, необходимо, чтобы она обладала характерными чертами материальной и духовной культуры, выражаемыми на определенном общепонятном языке. Поэтому, третьим, очень важным элементом любой общности, своего рода равнодействующей всех этногенетических факторов, является этническое самосознание» ${ }^{16}$.

Как признается британский социолог М.Ф. Бендл мы имеем дело не с идентификацией как таковой, а с подменой ею связи, имеющей место между конфессиональной и этнической принадлежностью, которая (связь) и объясняет, почему, например, «поляк-католик» отличает себя от «литовца-католика», «русский-православный» от «болгарина-православного», «узбек-мусульманин» от «казаха-мусульманина», «белорус-католик» от «белоруса-православного». В свою очередь сама эта связь, поскольку она исторически преходяща, опровергает всякое отождествление вероисповедания и национальности ${ }^{17}$.

Верующие, составляющие ту или иную общность, вне стен церкви представляют собой уже не только собственно верующих, членов того или иного религиозного сообщества. В миру они, прежде всего, являются просто гражданами, тружениками, «хозяйствующими субъектами», имеющими разнообразные земные проблемы социального, экономического, политического, культурного характера. Наряду с этим, они представляют собой различные этносоциальные общности, вступающие в определенные отношения друг с другом.

В каждой из подобных общностей исторические сложились своеобразные общественные отношения, образовались социальные структуры. По-разному про-

\footnotetext{
${ }^{16}$ Брук С.И., Чебоксаров Н.Н., Чеснов Я.В. Проблемы этнического развития стран зарубежной Азии // Вопросы истории. - 1969. - №1. - С 99.

${ }^{17}$ Bendle M.F. The crisis of 'identity' in high modernity // Brit. J. of sociology. - L., 2002. - №1.
} 
текали в них этнообразующие процессы. Все они имеют и сходные черты, и особенности. При их складывании имело место непосредственное воздействие конкретных конфессий на институциональные формы данных образований и социальное поведение членов этнических сообществ. Естественно, что этнообразующие процессы накладывали свои особенности на указанные конфессии ${ }^{18}$. Действительно, правомерно квалифицировать этноконфессиональную общность как специфический тип социальной общности людей с религиозно оформленным жизненным укладом, этническое самосознание которых выступает как религиозное, принимающее в конкретных социально-исторических условиях функции этнического определителя ${ }^{19}$.

По мнению современного исследователя этноконфессиональной проблематики С.П. Петренко, этнические и конфессиональные общности обладают следующими общими характерными признаками ${ }^{20}$ :

- $\quad$ самосознание (этническое или конфессиональное);

- $\quad$ название и самоназвание - эндоэтноним и эндоконфессионим;

- чувство солидарности;

- общность культурных традиций;

- $\quad$ эндогамия.

Отметим также, что в отечественной литературе в последние годы все чаще употребляются понятия «межрелигиозные отношения» и (нередко как синоним данных отношений, хотя в строго научном понимании это неверно) «межконфессиональные отношения». Действительно, в строгом смысле слова понятие «межрелигиозные отношения» должно употребляться применительно к взаимоотношениям последователей различных религий и их институтов, например, христианства, ислама, буддизма, в то время как «межконфессиональные отношения» должны характеризовать

${ }^{18}$ См. например: Амелин В.В. Этноконфессиональные отношения в оценках и представлениях массового сознания оренбуржцев // Журнал социологии и социальной антропологии. 2002, Том V.- №4.- С. 59-85; Султангалиев А.А. Религия и этнические общности. - Уфа:, 1997. - С43; Роль религии в формировании южнославянских наций / Под ред. И.В. Чуркиной. - М.: , 1999. - С. 11.

19 Разин, А.С. О категории «этноконфессиональное» в социальной философии / Наука. Философия. Общество. Материалы V Российского философского конгресса / А.С. Разин. Том II. - Новосибирск: 2009, С. 526.

${ }^{20}$ См. об этом: Петренко С.П. Конфессиональная общность и этнос: сходства и различие // Гуманитарные и социальноэкономические науки. - 2006. - №12. - С.14-18. отношения между последователями и институтами конкретных конфессий в рамках одного религиозного течения (например, между православными, католическими и протестантскими объединениями). Вся совокупность представленных выше отношений может фиксироваться в понятии «религиозно-конфессиональные отношения», предложенном Ю.П. Зуевым и Н.В. Трусеневой ${ }^{21}$. Так как данное «синтетическое» определение наиболее полно раскрывает сущность этих сложных социальных отношений.

Наряду с отмеченным различением межрелигиозных и межконфессиональных отношений, в отечественном религиоведении сложилась и расширительная трактовка последнего вида отношений. В межконфессиональный вид отношений включаются не только отношения между представителями конфессий и конфессиональными организациями, но и между представителями различных религий и их организациями ${ }^{22}$. Соответственно этому, когда мы употребляем понятие «этноконфессиональные отношения», то имеем в виду как сложное взаимодействие между этническими общностями, их институтами и этнофорами, так и последователями разных религий и существующих в их рамках конфессий. Они касаются субъектов религий и конфессий: религиозных групп, органов управления религиозных объединений, служителей церквей и религиозных объединений.

Таким образом, этноконфессиональные отношения - это сложный и активно воздействующий на общественную жизнь современной России феномен. Анализ этого феномена позволяет установить конкретную роль религиозного фактора и его функций в многонациональном российском социуме, а также выявить взаимосвязи между этнонациональным и религиозным сознанием россиян, между их этнокультурными и религиозными ценностями.

Термины «религиозный фактор», «этнический фактор» в последние годы становятся все более употреби-

\footnotetext{
21 Зуев Ю.П., Трусенева Н.В. Религиозно-конфессиональные отношения в современной России // Государственно-церковные отношения в России. В 2-х тт. - М., 1995. - С.155.

${ }^{22}$ См.: Абдулагатов 3. Российские православные и мусульмане: общие проблемы - разные взгляды // Социс. - 2004. - №2. - С.153 - 154; Андреева Л.А., Ряховский В.В. Православие, протестантизм и стратегия устойчивого развития России в начале XXI в // Общественные науки и современность. - 2004. - №3. - с. 143 - 153; Цеханская К.В. Россия: тенденции религиозности в XX веке // Исторический вестник. -2000 . - №5.
} 


\section{Политика и общество 2 (98) • 2013}

тельными в общественных науках, в частности в религиоведении, политологии, этнологии, социологии, постепенно обретая качества и статус научного понятия, характеризующего определенные общественные явления. Однако в большинстве публикаций эти понятия употребляется пока без четкого определения, что порождает их многозначность и затрудняет применение в качестве инструмента научного познания ${ }^{23}$.

Латинское слово factor (в современном переводе - «делающий», «производящий») ${ }^{24}$. Изначально оно имело совершенно конкретное, имеющее к человеку содержание. Так, по «Латинско - русскому и руссколатинскому лексикону» И. Кронеберга (1870 г.) слово factor толкуется как «деятель, художник, мастер чего-либо» (со ссылкой на Катулла) и как «автор, творец чего-то» (со ссылкой на Ульпиана Юрисконсульта) $)^{25}$. Впоследствии содержание и сфера применения этого термина расширились, он вошел в математику, где стал означать «множитель».

Переходным от общенаучного понятия «фактор» к конкретно интересующему нас понятию «религиозный фактор» является общефилософское и социологическое понятие «социальный фактор». С.А. Войтович дает свое определение, считая, что «фактор социальный - это движущая сила развития общества; явление или процесс, обусловливающий те или иные социальные изменения. В основе такого выделения лежит такая связь социальных объектов, при которой одни из них (причины) при определенных условиях с необходимостью порождают другие социальные объекты или их свойства (следствия). В качестве «Фактора социального» выступает, прежде всего, деятельность людей, обусловливающая в конечном итоге все многообразие социальной жизни общества» ${ }^{26}$.

Применительно к религии, речь может идти как о факторах, влияющих на состояние, изменение, развитие самой религии и составляющих ее элементов.

\footnotetext{
${ }^{23}$ См., в частности. Данакари Р. А. Этническое бытие: монография. - Волгоград: ИПК «Нива», 2007. С. 54.; Денисова Г.С., Радовель М.Р. Этносоциология. - Ростов-н/Д:, 2000. С. 236.

${ }^{24}$ См.: Словарь иностранных слов.-18-е изд., стер. - М.: .,1989.-С. 530.

${ }^{25}$ См.: Латинско-русский и русско-латинский лексикон, с полным объяснением свойств и значений каждого слова, с показанием собственных имен древней географии и мифологии, составленной Иваном Кронебергом. Седьмое издание. - М., 1870. - С. 176.

26 Войтович С.A. Фактор социальный: социологический справочник. - Киев. -1990.- С. 117.
}

Это факторы эволюции религии, религиозного сознания, факторы стабильности или изменения религиозной ситуации, межконфессиональных отношений. Они выступают в ситуациях и процессах в обществе, стране, регионе, относительно которых сама религия или ее составляющие, конкретные проявления выступают факторами их состояния и динамики. Важно принять религию как фактор духовного состояния общества, как фактор стабильности или обострения межнациональных отношений. Именно в последнем случае правомерно употребление понятия «религиозный фактор», так как здесь прослеживается внешнее воздействие, оказываемое религией.

В современной научной литературе пока отсутствует системное видение и сущность понятия «религиозный фактор». Однако его значимость выделяют многие авторы, выявляя при этом наиболее характерные черты. Так, И.Н. Сударев пишет: «Россия как многоконфессиональная страна представляет собой уникальное явление. Особое значение религиозный фактор приобретает на решающих, поворотных этапах ее развития. Его можно использовать как большое благо для страны. Основные религиозные конфессии при правильно построенной государственной политике в этой области могут быть союзниками государства в деле построения современной, мощной, процветающей России, способны содействовать ее внутренней стабильности, играть консолидирующую роль в обществе» ${ }^{27}$.

Отметим, что в настоящее время большинство религий, существующих в России, умело адаптировались к рыночной системе, пропагандируют человека на активный образ жизни, призывают к экономической деятельности, потому что опираются на здравый смысл, практические и рациональные аргументы.

Видные представители всех конфессий предлагают вернуть экономике ее подлинную ценность, их критика направлена скорее не на экономическую, а на этическую и культурную систему. Экономика предстает просто как одна из сторон человеческой жизнедеятельности. Следуя этическому постулату, иерархи христианских церквей полагают, что когда производство и потребление становятся смыслом жизни, причину этого следует искать не в экономике, а в ослаблении культуры, забвении нравственности, что общество свело весь смысл жизни к производству товаров, употреблению, удобствам и роскоши.

${ }^{27}$ Религиозный фактор в современной России - М., 1996. № 25, С. 120. 
Рассматривая православие, отметим, что в современной России оно уже по праву заняло свое основное и доминирующее место среди всех конфессиональных общностей. Сегодня она может сыграть особую роль в обеспечении социально-политической стабильности и консолидации общества. Призывая человека любить мир, православие в то же время зовет его к освобождению от мира, чтобы он ставил духовные интересы выше материальных, понимал, что не создание земных ценностей есть главная цель человеческой жизни, смысл его бытия. Приоритет духовного над материальным, христианский аскетизм и служение обществу как религиозная установка создают особые отношения между людьми.

Православие выработало собственный эталон жизни и деятельности. В отличие от протестантского утилитаризма, оно изначально исходило из несколько иных нравственных критериев, которые востребованы в российском обществе. В противоположность протестантскому «предопределению к спасению» и «оправданию верой», этической нормой православия является «хождение перед Богом с мыслью об ответственности перед ним». Для православия успех деятельности, успех предпринимательства, величина приносимой прибыли никогда не являлись доказательством нравственной и этической оправданности. Система ценностей, созданная православием, принципы его рациональной деятельности и отношения к человеку и его труду могут стать основой российской модернизации, дать положительный импульс развитию мелкого и среднего бизнеса.

Таким образом, в качестве религиозного фактора у И.Н. Сударева выступает многоконфессиональность России. Объектом его воздействия является внутриполитическая ситуация, а предполагаемым и желательным результатом этого воздействия - внутренняя стабильность государства и консолидация общества. Обращает на себя внимание инструментальный подход автора к данному явлению. Он считает, что религиозный фактор «можно использовать» в государственной политике.

Существуют еще несколько позиций. Относительно емкое определение исследуемого понятия предложил А.А. Нуруллаев, который пишет: «Религиозный фактор есть специфическое обозначение функционирования религии и ее институтов в системе социальных, экономических, политических, национальных и других отношений; все, что относится к религии и ее институтам как субъекту деятельности в разных сфе- pax общественной жизни» ${ }^{28}$. По его мнению, в посттоталитарный период, в условиях формирования демократического гражданского общества действует тенденция усиления влияния религиозного фактора на различные стороны жизни.

В указанном определении существенно то, что в качестве религиозного фактора берется не религия сама по себе, а ее функционирование. Важно также, что религиозные институты рассматриваются в качестве субъектов деятельности. Из этого следует, что если религия как социальное явление потенциально всегда является фактором общественной жизни, то превращение ее в реальный фактор различных общественных процессов и общественной жизни в целом происходит путем осуществления религией своих социальных функций, через целенаправленную деятельность религиозных институтов. А поскольку религиозные институты и организации всегда имеют конфессиональную определенность, то религиозный фактор в большинстве случаев предстает в виде конфессионального фактора или порождается взаимоотношениями между конфессиями.

Более полному и всестороннему исследованию в качестве конфессионального фактора в отечественной науке подвергается и исламский фактор. В трудах исламоведов, востоковедов, политологов, в исследованиях специалистов по международным отношениям этот термин утвердился с 60-70-х гг. ХХ века. Они были связаны с началом арабо-израильского конфликта, нарастанием национально-освободительной борьбы и процессами модернизации во многих странах исламского мира.

В работах Л.А. Баширова, А.В. Журавского, А.А. Игнатенко, А.И. Ионова, Г.М. Керимова, В.И. Корнева, А.В. Малашенко, Г.В. Милославского, Е.М. Примакова дается не только определение исламского фактора, но раскрываются и его особенности, структура и содержание ${ }^{29}$. В качестве

\footnotetext{
${ }^{28}$ Нуруллаев А.А. Религиозный фактор в национальных процессах // Государственно-церковные отношения в России. М.: , 1994.-Ч. 1.-С. 100.; Волобуев В.А. Исламский фатализм: стереотип или мировоззренческая установка? // Философия хозяйства. - 2009. - №6(66). - С. 215.

${ }^{29}$ См. например: Примаков Е.М. Ислам и общественное развитие в странах зарубежного Востока. М.:, 1982; Мальщшева Д.Б. Религиозный фактор в вооруженных конфликтах современности. - М.: Наука, 1991; Малашенко А.В. Ислам как фактор восстановления СССР // Россия и мусульманский мир, 1993, №10 и др.
} 


\section{Политика и общество 2 (98) • 2013}

фактора общественной жизни (международных отношений, национально-освободительной борьбы, противостояния Восток-Запад, экономического и политического развития стран Ближнего и Среднего Востока и т.д.) рассматриваются как ислам в целом, так и его компоненты и производные, вероучение и традиции, мусульманский образ жизни, исламская солидарность. Проблему исламского фактора через призму искусства рассматривают в своей работе М.В. Иордан и Р.Г. Кузеев ${ }^{30}$. Однако это тема совершенно другого научного исследования.

Отечественный исламовед Г.В. Милославский усматривает специфическую особенность «исламского фактора» в политике в том, что он может проявляться одновременно как в группе элементов внешней политики, обусловленных внутренней сущностью государства, так и среди факторов влияния внешней среды. Иными словами, рассматривая роль «исламского фактора» во внешней политике государства, мы сталкиваемся как бы с двойным его влиянием: «изнутри» ${ }^{31}$, в силу включенности ислама в общественные институты, и «снаружи», под воздействием других субъектов международных отношений ${ }^{32}$.

Однако в нашем общественном сознании существуют значительные предубеждения в отношении такой мировой религии как ислам. Многие догматы ислама сегодня могут быть использованы для консолидации общества, модернизации экономики. Например, догмат о предопределении может быть интерпретирован совершенно в кругом значении. Теперь он не сковывает человеческое сознание и парализует его активность. Идея божественной предопределенности означает, что человек в исламе, борясь за собственное благо, выполняет еще волю Аллаха. «Активность индивида в достижении практических целей, - пишет А.А. Гусейнов, - зависит не столько от сознания того, что он борется за свои цели, сколько от убежденности в том, что это - ис-

\footnotetext{
${ }^{30}$ Иордан М.В., Кузеев Р.Г., Червонная С.М. Ислам в Евразии: современные этические концепции суннитского Ислама, их трансформация в массовом сознании и выражение в искусстве мусульманских народов России. - М.: 2001. С. 212.

${ }^{31}$ См. например: Милославский Г.В. Интеграционные процессы в мусульманском мире. М., 1991. С.127.; Драмбян М.И. Ислам как фактор общественной жизни в Республике Дагестан // Этнографическое обозрение. - 2009. - №4. - С. 51.

${ }^{32} \mathrm{http}$ ://www.newhorizon-slamicbanking.com/index.cfm?=breaknew saction.
}

тинные цели» ${ }^{33}$. Апелляция же к воле Бога есть признание высшей степени истинности.

Огромное количество фактов из истории и современной жизни мусульманских народов свидетельствуют о том, как тесно и органически сочетались религиозное вдохновение с энергичной деятельностью во имя Аллаха. Они опровергают суждения о сковывающем влиянии идеи предопределения на человеческую жизнь. Божественное провидение совершается через посредство вещей и событий земного мира. Для того, чтобы угодить Аллаху, следует поступать соответственно объективной мере вещей, т.е. наилучшим, наичестнейшим образом выполнять свое дело.

Соблюдение таких моральных заповедей ислама, как честность, правдивость, справедливость, неприятие воровства, прелюбодеяния, причинения вреда, являются залогом человеческого общежития. Особое значение следует придавать таким чертам характера и добродетелям, которые формируют личность, способствуют его развитию и самореализации. Поэтому при пропаганде идей ислама следует руководствоваться общим благом, которое в своей основе имеет жизненный опыт и здравый смысл, позволяет ориентироваться в жизни на личный успех, волевую и предприимчивую, активную и энергичную деятельность. Важно также по-другому рассматривать отношение к труду и трудовой активности. Используя традиции исламской религии, в многоконфессиональной России можно свободно возводить в категорию «нравственный долг» и рассматривать его как умение эффективно трудиться на благо общества, семьи и самого себя.

Подводя итоги, отметим, что, сегодня религия, будучи активной подсистемой социума, со своими многообразными связями переплелась с другими компонентами общественной системы. Она является реальным фактором общественных процессов, не только пропагандирует свои идеи, но и активно реализует социальную миссию. Отсюда, не случайно, что в нашей религиоведческой и философской литературе достаточно подробно и широко рассматривается роль и место этнических и конфессиональных общностей в начавшейся модернизации общества. Анализ социальных функций религии, необходимость выявления ее универсальных характеристик становится велением времени.

Успехи модернизации развитых стран, в первую очередь, связаны с тем, что они опирались не толь-

\footnotetext{
${ }^{33}$ Гуссейнов А.А. Великие моралисты. М., 1995. С. 141.
} 
ко на собственно экономические, социальные и политические основы, но и на специфику и своеобразие культурных, этнических и конфессиональных характеристик общества. Они отвечали внутренним потребностям общественного развития западных государств, позволили решить назревшие социальные конфликты, построить гармоничное и справедливое общество.

В современных условиях борьбы за социальную и политическую стабильность в России этноконфессиональный фактор отражает единство в многообразие нашего общества. Поэтому решающее значение приобретает использование положительного потенциала религий, их способности объединить общности, коллективы, общины («умма») через выполнение различных социальных, экономических, трудовых, хозяйственных функций, формы культурного и культового действия, ритуалы и обряды ${ }^{34}$.

Действительно, долгий опыт российских реформ, периодические повторяющиеся социально-экономические кризисы, девальвация ценностей еще раз убеждают нас в том, что никакая общественная система не сможет выбраться из конфликтов, начать возрождение и развитие, достигнуть успеха, пока не будет опираться на свое историческое и культурное наследие, духовный потенциал народов.

\section{Библиография:}

1. Абдулагатов 3. Российские православные и мусульмане: общие проблемы - разные взгляды // Социс. - 2004. - №2. - С.153 - 154;

2. Амелин В.В. Этноконфессиональные отношения в оценках и представлениях массового сознания оренбуржцев // Журнал социологии и социальной антропологии. 2002, Том V.- №4.- C. 59-85;

3. Андреева Л.А., Ряховский В.В. Православие, протестантизм и стратегия устойчивого развития России в начале XXI в // Общественные науки и современность. - 2004. - №3. - с. 143 - 153;

4. Бат-Йеор. Зимми. Евреи и христиане под властью ислама: Т.1.- М., Иерусалим, 1991.- С. 23-45.

5. Брук С.И., Чебоксаров Н.Н., Чеснов Я.В. Проблемы этнического развития стран зарубежной Азии // Вопросы истории. - 1969. - №1. - С 99.

\footnotetext{
${ }^{34}$ См. об этом: Разин А.С. Истоки хозяйства (ритуал, обряд, традиция) // Гуманитарные и социально-экономические науки. - 2006. - №12. - С.105.
}

6. Бушар Мишель Православие как идеологическая основа становления русской нации // Этнографическое обозрение. 2002. №4 с.139-149.

7. Войтович С.А. Фактор социальный: социологический справочник. - Киев. -1990.- С. 117.

8. Волобуев В.А. Исламский фатализм: стереотип или мировоззренческая установка? // Философия хозяйства. - 2009. - №6(66). - С. 215.

9. Гуссейнов А.А. Великие моралисты. М., 1995. С. 141 .

10. Данакари Р. А. Этническое бытие: монография. - Волгоград: ИПК «Нива», 2007. С. 54.; Денисова Г.С., Радовель М.Р. Этносоциология. - Ростовн/Д: Изд-во ООО «ЦВВР», 2000. С. 236.

11. Достоян И.С. Карасев А.В. Православная церковь и складывание сербской нации // Роль религии в формировании южнославянских наций. Под ред. И.В. Чуркиной. - М.: Эдиториал УРСС, 1999. - С. 138.

12. Драмбян М.И. Ислам как фактор общественной жизни в Республике Дагестан // Этнографическое обозрение. - 2009. - №4. - С. 51.

13. Дюркгейм Э. Социология религии и теория познания // Религия и общество. - М.-1996. С 113.

14. Зуев Ю.П., Трусенева Н.В. Религиозно-конфессиональные отношения в современной России // Государственно-церковные отношения в России. В 2-х тт. - М., 1995. - С.155.

15. Иордан М.В., Кузеев Р.Г., Червонная С.М. Ислам в Евразии: современные этические концепции суннитского Ислама, их трансформация в массовом сознании и выражение в искусстве мусульманских народов России. - М.: Прогресс-Традиция 2001. С. 212.

16. Ипатов А.Н. Православие и русская культура. М.: Сов. Россия, 1985. С.22.

17. Корнев В.И. Феномен религии // Азия и Африка сегодня.-1994.-№1. с. 33.

18. Латинско-русский и русско-латинский лексикон, с полным объяснением свойств и значений каждого слова, с показанием собственных имен древней географии и мифологии, составленной Иваном Кронебергом. Седьмое издание. - М., 1870. - С. 176.

19. Малашенко А.В. Ислам как фактор восстановления СССР // Россия и мусульманский мир, 1993, №10 и др.

20. Малышева Д.Б. Религиозный фактор в вооруженных конфликтах современности. - М.: Наука, 1991; 


\section{Политика и общество 2 (98) • 2013}

21. Милославский Г.В. Интеграционные процессы в мусульманском мире. М., 1991. С.127.;

22. Мирский Г. Этнос, религия, национализм//Азия и Африка сегодня. 1994. №2. С.4.

23. Митрохин Л.Н. Философия религии: новые перспективы // Вопр. философии.-2003.-№8. С.23.

24. Нуруллаев А.А. Религиозный фактор в национальных процессах // Государственно-церковные отношения в России. - М.: РАГС, 1994.Ч. 1.-С. 100.;

25. Петренко С.П. Конфессиональная общность и этнос: сходства и различие // Гуманитарные и социально-экономические науки. - 2006. - №12. C.14-18.

26. Пивоваров Д.В. Религия: взаимосвязь натуроцентрической и социоцентрической форм // Религия, общество и государство в ХХ в. М., 1991. С.102.

27. Примаков Е.М. Ислам и общественное развитие в странах зарубежного Востока. М.: Политиздат, 1982;

28. Рагузин В.Н. На острие российской геополитики. - М.: Изд-во РАГС, 1999.c.74.

29. Разин А.С. Истоки хозяйства (ритуал, обряд, традиция) // Гуманитарные и социально-экономические науки. - 2006. - №12. - С.105-110.

30. Разин, А.С. О категории «этноконфессиональное» в социальной философии / Наука. Философия. Общество. Материалы V Российского философского конгресса / А.С. Разин. Том II. - Новосибирск: Параллель, 2009, С. 526.

31. Разин, А.С. Этноконфессиональные факторы хозяйствования в постиндустриальном обществе // Философия и культура / А.С. Разин, А.В. Белов 2012, - №3, - С. 54-65.

32. Религиозный фактор в современной России // Клуб «Реалисты»: информационно-аналитический бюллетень: («Религия. Общество. Государство» материалы круглого стола). - М., 1996.-№ 25, С. 120.

33. Роль религии в формировании южнославянских наций / Под ред. И.В. Чуркиной. - М.: Эдиториал УРСС, 1999. - С. 11.

34. Словарь иностранных слов.-18-е изд., стер. - М.: Рус. Яз.,1989.-С. 530.

35. Султангалиев А.А. Религия и этнические общности. - Уфа: Изд-во БГУ, 1997. - С43;

36. Цеханская К.В. Россия: тенденции религиозности в XX веке // Исторический вестник. - 2000. - №5.

37. Bendle, M.F. The crisis of 'identity' in high modernity // Brit. J. of sociology. - L., 2002. - №1.
38. Brubaker, R. Ethnicity as cognition/ R.Brubaker, M. Loveman, P. Stamatov //Theory a. society. Dordrecht, 2004. - N 33. - P.31-64.

39. Firth, R. Religion in social reality / R. Firth // Elements of social organization. - L.: Watts \& Co., 1951. - P.215-250.

40. http://www.newhorizon-slamicbanking.com/index. cfm?=breaknew saction.

41. Marody, M. On functions of religion in molding the national identity of poles / M. Marody, S. Mandes // Intern. J. of sociology. - Annonk, 2005-2006. - N 4. - P. 49-68.

42. Schnee, W. Nationalism: A review of the literature / W. Schnee // J. of polit. a. milit. sociology. - New Brunswick, 2001. - N 1. - P. 1-18.

\section{References (transliteration):}

1. Abdulagatov Z. Rossiyskie pravoslavnye i musul'mane: obshchie problemy - raznye vzglyady // Sotsis. - 2004. - №2. - S.153 - 154;

2. Amelin V.V. Etnokonfessional'nye otnosheniya $\mathrm{v}$ otsenkakh i predstavleniyakh massovogo soznaniya orenburzhtsev // Zhurnal sotsiologii i sotsial'noy antropologii. 2002, Tom V.- №4.S. 59-85;

3. Andreeva L.A., Ryakhovskiy V.V. Pravoslavie, protestantizm i strategiya ustoychivogo razvitiya Rossii v nachale XXI v // Obshchestvennye nauki i sovremennost'. - 2004. - №3. - s. 143 - 153;

4. Bat-Yeor. Zimmi. Evrei i khristiane pod vlast'yu islama: T.1.- M., Ierusalim, 1991.- S. 23-45.

5. Bruk S.I., Cheboksarov N.N., Chesnov Ya.V. Problemy etnicheskogo razvitiya stran zarubezhnoy Azii // Voprosy istorii. - 1969. - №1. - S 99.

6. Bushar Mishel' Pravoslavie kak ideologicheskaya osnova stanovleniya russkoy natsii // Etnograficheskoe obozrenie. 2002. №4 s.139-149.

7. Voytovich S.A. Faktor sotsial'nyy: sotsiologicheskiy spravochnik. - Kiev. -1990.- S. 117.

8. Volobuev V.A. Islamskiy fatalizm: stereotip ili mirovozzrencheskaya ustanovka? // Filosofiya khozyaystva. - 2009. - №6(66). - S. 215.

9. Gusseynov A.A. Velikie moralisty. M., 1995. S. 141.

10. Danakari R. A. Etnicheskoe bytie: monografiya. Volgograd: IPK «Niva», 2007. S. 54.; Denisova G.S., Radovel' M.R. Etnosotsiologiya. - Rostov-n/D: Izdvo OOO «TsVVR», 2000. S. 236. 
11. Dostoyan I.S. Karasev A.V. Pravoslavnaya tserkov' i skladyvanie serbskoy natsii // Rol' religii v formirovanii yuzhnoslavyanskikh natsiy. Pod red. I.V. Churkinoy.M.: Editorial URSS, 1999. - S. 138.

12. Drambyan M.I. Islam kak faktor obshchestvennoy zhizni v Respublike Dagestan // Etnograficheskoe obozrenie. - 2009. - №4. - C. 51.

13. Dyurkgeym E. Sotsiologiya religii i teoriya poznaniya // Religiya i obshchestvo. - M.-1996. S 113.

14. Zuev Yu.P., Truseneva N.V. Religiozno-konfessional'nye otnosheniya v sovremennoy Rossii // Gosudarstvenno-tserkovnye otnosheniya v Rossii. V 2-kh tt. M., 1995. - S.155.

15. Iordan M.V., Kuzeev R.G., Chervonnaya S.M. Islam v Evrazii: sovremennye eticheskie kontseptsii sunnitskogo Islama, ikh transformatsiya v massovom soznanii $\mathrm{i}$ vyrazhenie v iskusstve musul'manskikh narodov Rossii. - M.: Progress-Traditsiya 2001. S. 212.

16. Ipatov A.N. Pravoslavie i russkaya kul'tura. - M.: Sov. Rossiya, 1985. S.22.

17. Kornev V.I. Fenomen religii // Aziya i Afrika segodnya.-1994.-№1. s. 33.

18. Malashenko A.V. Islam kak faktor vosstanovleniya SSSR // Rossiya i musul'manskiy mir, 1993, №10 i dr.

19. Malysheva D.B. Religioznyy faktor v vooruzhennykh konfliktakh sovremennosti. - M.: Nauka, 1991;

20. Miloslavskiy G.V. Integratsionnye protsessy v musul'manskom mire. M., 1991. S.127.;

21. Mirskiy G. Etnos, religiya, natsionalizm//Aziya i Afrika segodnya. 1994. №2. S.4.

22. Mitrokhin L.N. Filosofiya religii: novye perspektivy // Vopr. filosofii.-2003.-№8. S.23.

23. Nurullaev A.A. Religioznyy faktor v natsional'nykh protsessakh // Gosudarstvenno-tserkovnye otnosheniya v Rossii. - M.: RAGS, 1994.-Ch. 1.-S. 100.;

24. Petrenko S.P. Konfessional'naya obshchnost' i etnos: skhodstva i razlichie // Gumanitarnye i sotsial'noekonomicheskie nauki. - 2006. - №12. - S.14-18.

25. Pivovarov D.V. Religiya: vzaimosvyaz' naturotsentricheskoy i sotsiotsentricheskoy form // Re- ligiya, obshchestvo i gosudarstvo v KhKh v. M., 1991. S.102.

26. Primakov E.M. Islam i obshchestvennoe razvitie v stranakh zarubezhnogo Vostoka. M.: Politizdat, 1982;

27. Raguzin V.N. Na ostrie rossiyskoy geopolitiki. - M.: Izd-vo RAGS, 1999.s.74.

28. Razin A.S. Istoki khozyaystva (ritual, obryad, traditsiya) // Gumanitarnye i sotsial'no-ekonomicheskie nauki. - 2006. - №12. - S.105-110.

29. Razin, A.S. O kategorii «etnokonfessional'noe» v sotsial'noy filosofii / Nauka. Filosofiya. Obshchestvo. Materialy V Rossiyskogo filosofskogo kongressa / A.S. Razin. Tom II. - Novosibirsk: Parallel', 2009, S. 526.

30. Razin, A.S. Etnokonfessional'nye faktory khozyaystvovaniya $v$ postindustrial'nom obshchestve // Filosofiya i kul’tura / A.S. Razin, A.V. Belov - 2012, - №3, - S. 54-65.

31. Rol' religii v formirovanii yuzhnoslavyanskikh natsiy / Pod red. I.V. Churkinoy. - M.: Editorial URSS, 1999. - S. 11.

32. Sultangaliev A.A. Religiya i etnicheskie obshchnosti. - Ufa: Izd-vo BGU, 1997. - S43;

33. Tsekhanskaya K.V. Rossiya: tendentsii religioznosti v XX veke // Istoricheskiy vestnik. - 2000. - №5.

34. Bendle, M.F. The crisis of 'identity' in high modernity // Brit. J. of sociology. - L., 2002. - №1.

35. Brubaker, R. Ethnicity as cognition/ R.Brubaker, M. Loveman, P. Stamatov //Theory a. society. - Dordrecht, 2004. - N 33. - P.31-64.

36. Firth, R. Religion in social reality / R. Firth // Elements of social organization. - L.: Watts \& Co., 1951. - P.215-250.

37. Marody, M. On functions of religion in molding the national identity of poles / M. Marody, S. Mandes // Intern. J. of sociology. - Annonk, 2005-2006. - N 4. - P. 49-68.

38. Schnee, W. Nationalism: A review of the literature / W. Schnee // J. of polit. a. milit. sociology. - New Brunswick, 2001. - N 1. - P. 1-18. 